\title{
Current practice and future perspective of the Prenatal Genetic Service in Slovenia
}

\author{
Marija Volk', Nataša Teran ${ }^{1}$, Aleš Maver ${ }^{1}$, Luca Lovrečić ${ }^{1}$, Borut Peterlin ${ }^{1,2}$
}

Prenatal genetic testing is under the remit of the National Health Service in Slovenia and has been included in clinical routine since the 1980s. Traditionally, prenatal services have consisted of karyotyping and rapid fetal aneuploidy screening to detect chromosome abnormalities, whereas targeted mutation testing was used for single gene disorders. Development of array comparative genomic hybridization and next generation sequencing allows for genome analysis at better resolution in a single experiment. While technological advances in medicine continue to evolve, increasing diagnostic accuracy and broadening the spectrum of indications, all these innovations require more investment along with more equipment and higher staffing rations trained to use it, placing burden upon healthcare funding and expenditure. This prompts us to consider how to implement new techniques into the existing services in order to update genetic services for the $21^{15 t}$ century. Our aim is to develop a new approach to prenatal genetic services, which would maximize diagnostic yield at an acceptable cost.

Keywords: genetic testing; genomic aberrations; prenatal diagnosis

\section{INTRODUCTION}

Genetic disorders represent a significant share of morbidity and mortality in pediatric population and are an important public health issue. Primary and secondary prevention genetic services are intended to prevent birth defects, genetic disorders, or disease before it occurs or before birth. New technologies, which could be utilized in prenatal genetic diagnosis, call for modifications and adaptations of the existing healthcare system.

In this work, we present development of the prenatal genetic service, the actual conditions and our recommendations for the future under the National Health Service in Slovenia.

\section{TRADITIONAL APPROACH TO PRENATAL GENETIC DIAGNOSIS}

Prenatal genetic diagnosis has been available in Slovenia since 1980 (Figure 1). We started with karyotyping of amniotic fluid, followed by chorionic villus sampling (CVS) in 1984. Chromosome analysis has been offered to pregnant women of advanced age (37 years or above), women with abnormal ultrasound scan, positive screening test (Nuchal Translucency, Double or Triple Hormone Test), a live-born child or previous pregnancy with an identified chromosome abnormality, or because one parent carries a chromosomal rearrangement. Diagnostic yield of classical karyotype is approximately $3 \%$, excluding Down syndrome and other recognizable chromosomal syndromes (1). Full chromosome analysis has long been regarded as the gold standard for prenatal testing.

Prenatal detection of single gene disorders has been available since 1997 for couples where one parent carries an autosomal dominant or X-linked disease or both parents are carriers of an autosomal recessive disorder. The basic molecular genetic tests, such as targeted allele-specific polymerase chain reaction (PCR)-based or restriction fragment analysis methodologies, Sanger sequencing or Southern blot were used to detect single gene disorders. In cases of unknown mutation, indirect approach by linkage analysis was used.

\footnotetext{
${ }^{1}$ Clinical Institute of Medical Genetics, UMC Ljubljana, Ljubljana, Slovenia ${ }^{2}$ Department of Gynaecology and Obstetrics, UMC Ljubljana, Ljubljana, Slovenia
}

\section{Correspondence to:}

Professor Borut Peterlin, MD, PhD, Clinical Institute of Medical Genetics, Department of Gynecology and Obstetrics, UMC Ljubljana, Ljubljana, Slovenia, e-mail: borut.peterlin@guest.arnes.si

Primljeno/Received: 19. 2. 2015., Prihvaćeno/Accepted: 28. 4. 2015. 


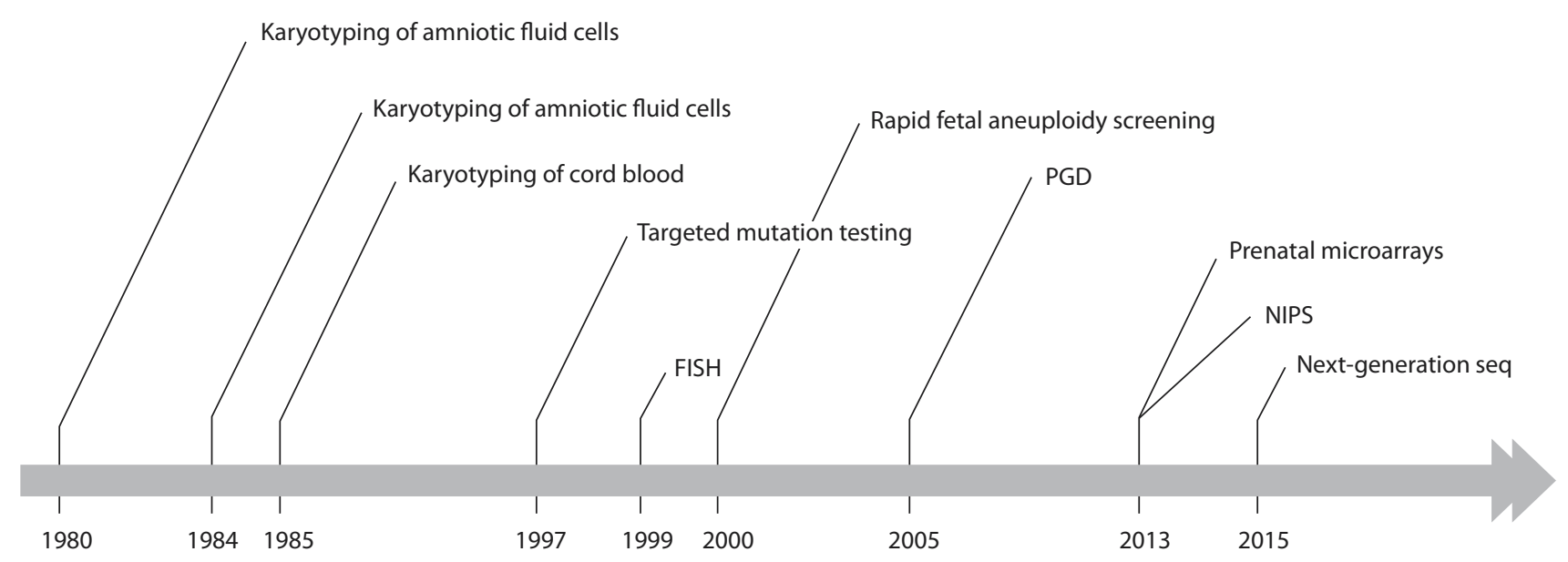

FIGURE 1. Development of the prenatal genetic service in Slovenia.

In 1998, we introduced the use of fluorescent in situ hybridization (FISH) in the prenatal setting. FISH allowed for detection of new categories: (a) genomic or submicroscopic mutations; and (b) rapid fetal aneuploidy testing, later replaced by other methods (qfPCR or MLPA). Rapid fetal aneuploidy screening was followed by karyotype analysis.

Fluorescent in situ hybridization has filled the gap between molecular and cytogenetic diagnostic tests. In addition, FISH allows for analysis of metaphase chromosomes or interphase nuclei. FISH probes are used to identify microdeletions (2), subtelomeric rearrangements (3), and origin of marker chromosome (4), or for simple and complex chromosome rearrangements on metaphase chromosomes, whereas rapid fetal aneuploidy screening and evaluation of mosaicism can be done on interphase nuclei.

We have been using interphase FISH method for preimplantation genetic diagnosis (PGD) in which one or two blastomeres are biopsied from the early embryo for FISH analysis of known familial chromosome rearrangements, or for sex selection in X-linked monogenic disease $(5,6)$.

\section{GENOMIC TESTS IN PRENATAL GENETIC DIAGNOSIS}

Now, we are facing genomic approaches. Array comparative genomic hybridization ( $\mathrm{aCGH}$ ) or molecular karyotyping can scan the entire genome to detect gains and losses of genetic material. aCGH was introduced into our routine in 2014, since the output is higher comparing to classical karyotyping, subtelomeric MLPA analysis or FISH. Prenatal $\mathrm{aCGH}$ is routinely used in the cases of ultrasound structural anomalies in the fetus, including nuchal translucency $>3.5$ $\mathrm{mm}$, and in the case of prenatally detected chromosomal rearrangements using karyotyping $(7,8)$. Clinically relevant genomic imbalances are reported in $4 \%-7 \%$ of fetuses with ultrasound detected structural anomalies $(7,9,10)$.
Some laboratories completely switched over their prenatal invasive diagnosis to aCGH (11). Apart from the fact that aCGH is more expensive compared to conventional karyotyping, there is another very important issue in prenatal diagnosis, i.e. how to deal with variants of unknown clinical significance (VOUS), susceptibility loci (SL) for neurodevelopmental disorders and unexpected diagnoses.

In addition, aCGH has become a tool for discovering regions prone to genomic rearrangements (12) and for identification of new deletion/duplication syndromes (13).

Moreover, Next Generation Sequencing (NGS) has radically changed the diagnosis of single gene disorders. It has shifted focus from the pre-NGS-test differential diagnostic mode to the post-NGS-test diagnostic assessment mode (14). NGS allows for multi-gene analysis in a single investigation (15). Since the implementation of NGS in the routine genetic testing, we have been increasingly harnessing its diagnostic potential to facilitate prenatal diagnosis. Whole human exome and genome sequencing based on NGS technology allows for comprehensive, rapid and accessible detection of a variety of mutational events in a patient with suspected genetic disease. Quality NGS service encompasses several steps, including proper pre-testing clinical assessment, massive parallel sequencing, and orthogonal validation with Sanger sequencing, data analysis and exhaustive interpretation. To ensure the timely and clinically valid diagnosis in the prenatal setting, we have been continuously optimizing each of these steps with the aim to reach 1-month referral-to-reporting time.

Recent reports indicate that exome sequencing facilitates prenatal genetic diagnosis (16-18). Early studies performed in pregnancies with ultrasound structural fetal abnormalities have reported conclusive detection rate of $10 \%$ in karyotype- and microarray-negative cases $(19,20)$. 


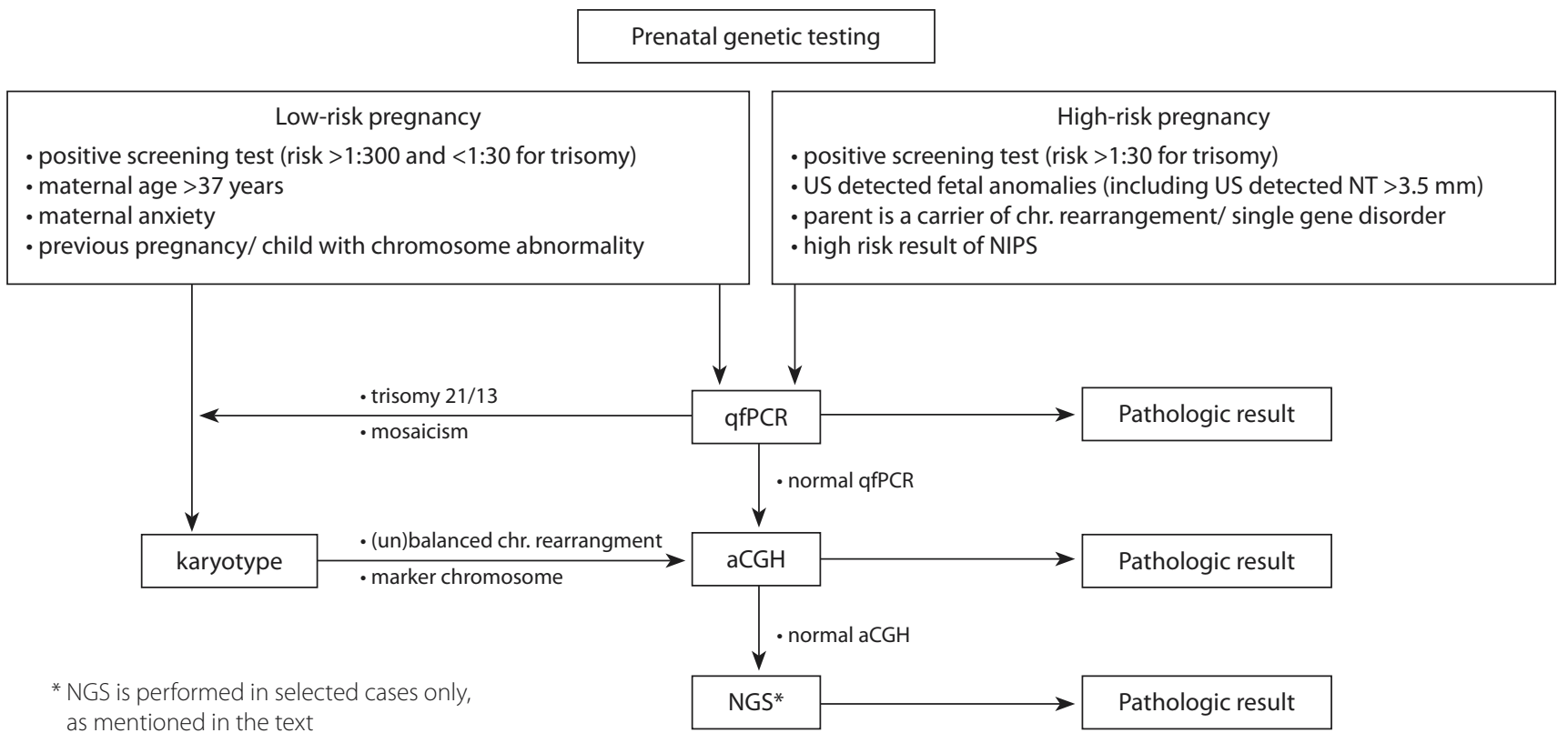

FIGURE 2. Flowchart of prenatal genetic testing approach.

The comprehensive nature of exome and genome sequencing also carries the issue of reporting variants of unknown significance, which are even more numerous than in microarray diagnosis. In our approach, we therefore limit the reporting of mutations only to those that are highly likely causative, which includes known pathogenic sequence variants and variants with certain impact (including non-sense and frameshift variants). Another challenge is the possibility of identifying unsolicited findings in genes, which may manifest postnatally. We currently focus the analysis only on findings pertinent to the referral diagnosis aiming to minimize the issue of identifying unwarranted incidental findings. The complexity of such a comprehensive and complex diagnosis in the prenatal period thus requires specific and sufficiently informative genetic counselling offered throughout the testing process.

The impact of NGS in a single gene landscape is analogous to aCGH in the cytogenetic domain. However, as NGS allows for detection of point mutations, small indels, CNVs and chromosome translocations (21), it is anticipated that aCGH will soon be replaced.

Since 2013, noninvasive prenatal screening (NIPS) can be offered to women with high-risk pregnancy (22). NIPS analyzes fetal DNA molecules, which are freed into the maternal circulation from the placental tissue. Professional Committee of the Slovenian Association of Medical Genetics currently recommends NIPS for pregnancies at a high risk of common trisomies, however, there is cumulative evidence of comparable NIPS test characteristics in low risk pregnancies. In Slovenia, NIPS is at the moment available on the pa- tient self-pay basis. NIPS test has high specificity (99\%) and sensitivity (>99\%) to detect fetal trisomy 21,18 , and 13 , yet it has been shown to be slightly less specific and sensitive for sex chromosome aneuploidy detection. Positive predictive value for trisomy 21 is around $45.5 \%$ (23), which is 10 times better than the classical prenatal screening tests (nuchal translucency, combined screening test or triple/ quadruple screening test).

\section{CURRENT PRACTICE AND FUTURE TRENDS}

Rapid development of new technologies in medical genetics increases the costs of genetic service. There is a need for a different approach, in which indication-matched tests would be used to maximize diagnostic yield at an acceptable cost.

Our prenatal genetic testing strategy specifies pregnant women into high-risk and low-risk pregnancies (Figure 2).

High-risk pregnancy is defined as a positive screening test with a risk of 1:30 or more for chromosome abnormality, ultrasound detected fetal anomalies, high risk result of NIPS, or if one parent is carrier of a Robertsonian translocation involving chromosome 13 or 21, and, in addition, any other balanced chromosomal rearrangement or a single gene disorder. In these cases, rapid testing for fetal aneuploidy screening (qfPCR) is performed first, followed by aCGH, when the qfPCR shows normal result. In the case of trisomy 21,13 or suspected chromosome mosaicism detected by qfPCR, karyotyping of the prenatal sample is recommended to clarify the chromosome constitution (Figure 2). 
Our approach considers aCGH indicated in cases of highrisk pregnancies only, based on professional and economic reasons. VOUS/SL co-findings can cause significant emotional distress for parents to be. On the other hand, resources intended for the prenatal genetic service program are limited.

Previously, targeted mutation testing was performed if there were ultrasound-detected anomalies possibly associated with a specific single gene disorder. Because of the genetic heterogeneity of the disorders and limitations of prenatal ultrasound to define fetal phenotype, the NGS approach will improve the performance. Since the introduction of NGS into our clinical routine, it has been demonstrated that the detection yield is far better than in other diagnostic tests currently in routine use. However, parents should be informed about the limitations of NGS and discuss it thoroughly at pre-test and post-test genetic counselling. A definitive genetic diagnosis would enable informed decisionmaking regarding continuation of the actual pregnancy and provide valuable information on the recurrence risk for future pregnancies.

On the other hand, low-risk pregnancies (advanced maternal age without any other screening test, previous pregnancy with chromosome aneuploidy and screening test with a risk higher than 1:300 and lower than 1:30) usually have normal gfPCR profile and karyotype, placing substantial financial burden upon healthcare budget, together with an increased risk of adverse pregnancy outcome because of the invasive procedure (CVS or amniocentesis). Similarly to some other European countries (24), we plan to offer rapid fetal aneuploidy testing as a stand-alone prenatal diagnostic test to pregnant women in low-risk group. Genetic counselling would be offered to pregnant women in low-risk group, where they would have an opportunity to discuss the advantages and limitations of the tests and would be offered a choice; they could opt between gfPCR and full chromosome karyotyping. In the case of abnormal karyotype, such as marker chromosome or unbalanced chromosome rearrangement, aCGH would be done to determine more accurately genomic gains or losses (Figure 2).

We are aware that rapid fetal aneuploidy testing cannot substitute full karyotype, since it gives information on numerical aberrations of chromosome 13, 18, 21 and sex chromosomes only, therefore, eventual reciprocal translocation, supernumerary marker chromosome or other rarer chromosome findings might be missed. However, in our experience, unbalanced chromosome rearrangements that could be detected by routine chromosome analysis are usually accompanied by developmental abnormalities of the fetus and would be detected by ultrasound examination of fetal morphology. It has been shown that rapid delivery of re- sults using qfPCR as a stand-alone test for pregnancies without ultrasound anomalies reduces parental anxiety (24).

At the Clinical Institute of Medical Genetics, among other genetic diagnostic procedures, PGD (pre-implantation genetic diagnosis) is available within the remit of the Health Service (no out of pocket expenses) for couples at a high risk of genetically disadvantaged offspring, either for chromosomal unbalanced rearrangement or single gene disorder.

\section{CONCLUSION}

We are witnessing rapid development of modern methodologies. However, technological advances are not always accompanied by the resources required to meet laboratory and medical needs. The challenge therefore is how to offer the best modern, rapid and appropriate medical services at an acceptable cost. In Slovenia, we have already introduced modern techniques into routine clinical practice. We are developing a strategy in the prenatal diagnostic setting to ensure best diagnostic yield with a combination of genetic tests at an affordable cost.

\author{
Abbreviations: \\ aCGH- array comparative genomic hybridization \\ NGS-next generation sequencing \\ CVS-chorionic villus sampling \\ PCR- polymerase chain reaction \\ FISH- fluorescent in situ hybridization \\ MLPA- multiplex ligation-dependent probe amplification \\ qfPCR- quantitative fluorescent polymerase chain reaction \\ NIPS- noninvasive prenatal screening \\ PGD- pre-implantation genetic diagnosis \\ CNV- copy number variant \\ VOUS- variant of unknown significance \\ SL- susceptibility locus
}

\section{NOVČANA POTPORAVFUNDING}

Nema/None

\section{ETIČKO ODOBRENJE/ETHICAL APPROVAL}

Nije potrebno/None

\section{DOPRINOSI AUTORAVDECLARATION OF AUTHORSHIP}

Svi autori jednako su doprinijeli izradi rada/All authors have equally contributed to a manuscript writing

\section{SUKOB INTERESA/CONFLICT OF INTEREST}

Autori su popunili the Unified Competing Interest form na www.icmje.org/ coi_disclosure.pdf(dostupno na zahtjev) obrazac i izjavljuju: nemaju potporu niti jedne organizacije za objavljeni rad; nemaju financijsku potporu niti jedne organizacije koja bi mogla imati interes za objavu ovog rada u posljednje 3 godine; nemaju drugih veza ili aktivnosti koje bi mogle utjecati na objavljeni rad./All authors have completed the Unified Competing Interest form at www.icmje.org/coi_disclosure.pdf (available on request from the corresponding author) and declare: no support from any organization for the submitted work; no financial relationships with any organizations that might have an interest in the submitted work in the previous 3 years; no other relationships or activities that could appear to have influenced the submitted work. 


\section{REFERENCES}

1. Miller DT, Adam MP, Aradhya S, et al. Consensus statement: chromosomal microarray is a first-tier clinical diagnostic test for individuals with developmental disabilities or congenital anomalies. Am J Hum Genet. 2010;86:749-64. http://dx.doi.org/10.1016/j.ajhg.2010.04.006

2. Shaffer LG. Diagnosis of microdeletion syndromes by fluorescence in situ hybridization (FISH). Curr Protoc Hum Genet. 2001;Chapter 8:Unit 810

3. Slavotinek A, Rosenberg M, Knight S, et al. Screening for submicroscopic chromosome rearrangements in children with idiopathic mental retardation using microsatellite markers for the chromosome telomeres. J Med Genet. 1999;36:405-11.

4. Nietzel A, Rocchi M, Starke H, et al. A new multicolor-FISH approach for the characterization of marker chromosomes: centromere-specific multicolor-FISH (cenM-FISH). Hum Genet. 2001;108:199-204. http://dx.doi.org/10.1007/s004390100459

5. Scriven PN, Ogilvie CM. FISH for pre-implantation genetic diagnosis. Methods Mol Biol. 2010;659:269-82. http://dx.doi.org/10.1007/978-1-60761-789-1_20

6. Sermon K, Van Steirteghem A, Liebaers I. Preimplantation genetic diagnosis. Lancet. 2004;363:1633-41. http://dx.doi.org/10.1016/S0140-6736(04)16209-0

7. Faas BH, Feenstra I, Eggink AJ, et al. Non-targeted whole genome 250K SNP array analysis as replacement for karyotyping in fetuses with structura ultrasound anomalies: evaluation of a one-year experience. Prenat Diagn. 2012;32:362-70. http://dx.doi.org/10.1002/pd.2948

8. Lovrečić L, Peterlin B. Uporaba molekularne kariotipizacije v klinični genetiki. Zdravniški vestnik. 2013;82:669-76.

9. Shaffer LG, Dabell MP, Fisher AJ, et al. Experience with microarray-based comparative genomic hybridization for prenatal diagnosis in over 5000 pregnancies. Prenat Diagn. 2012;32:976-85 http://dx.doi.org/10.1002/pd.3945

10. Hillman SC, Pretlove S, Coomarasamy A, et al. Additional information from array comparative genomic hybridization technology over conventional karyotyping in prenatal diagnosis: a systematic review and meta-analysis. Ultrasound Obstet Gynecol. 2011;37:6-14. http://dx.doi.org/10.1002/uog.7754

11. Vanakker $\mathrm{O}$, Vilain C, Janssens $\mathrm{K}$, et al. Implementation of genomic arrays in prenatal diagnosis: the Belgian approach to meet the challenges. Eur J Med Genet. 2014;57:151-6. http://dx.doi.org/10.1016/j.ejmg.2014.02.002
12. Shaw CJ, Lupski JR. Implications of human genome architecture for rearrangement-based disorders: the genomic basis of disease. Hum Mol Genet. 2004;13:R57-64. http://dx.doi.org/10.1093/hmg/ddh073

13. Weise A, Mrasek K, Klein E, et al. Microdeletion and microduplication syndromes. J Histochem Cytochem. 2012;60:346-58. http://dx.doi.org/10.1369/0022155412440001

14. Hennekam RC, Biesecker LG. Next-generation sequencing demands next-generation phenotyping. Hum Mutat. 2012;33:884-6. http://dx.doi.org/10.1002/humu.22048

15. Gilissen C, Hoischen A, Brunner HG, Veltman JA. Unlocking Mendelian disease using exome sequencing. Genome Biol. 2011;12:228. http://dx.doi.org/10.1186/gb-2011-12-9-228

16. Talkowski ME, Ordulu Z, Pillalamarri V, et al. Clinical diagnosis by whole-genome sequencing of a prenatal sample. N Engl J Med. 2012;367:2226-32. http://dx.doi.org/10.1056/NEJMoa1208594

17. Yang Y, Muzny DM, Reid JG, et al. Clinical whole-exome sequencing for the diagnosis of mendelian disorders. N Engl J Med. 2013;369:1502-11. http://dx.doi.org/10.1056/NEJMoa1306555

18. Filges I, Nosova E, Bruder E, et al. Exome sequencing identifies mutations in KIF14 as a novel cause of an autosomal recessive lethal fetal ciliopathy phenotype. Clin Genet. 2014;86:220-8. http://dx.doi.org/10.1111/cge.12301

19. Carss KJ, Hillman SC, Parthiban V, et al. Exome sequencing improves genetic diagnosis of structural fetal abnormalities revealed by ultrasound. Hum Mol Genet. 2014;23:3269-77. http://dx.doi.org/10.1093/hmg/ddu038

20. Hillman SC, Willams D, Carss KJ, McMullan DJ, Hurles ME, Kilby MD. Prenatal exome sequencing for fetuses with structural abnormalities: the next step. Ultrasound Obstet Gynecol. 2015;45:4-9. http://dx.doi.org/10.1002/uog.14653

21. Ku CS, Vasiliou V, Cooper DN. A new era in the discovery of de novo mutations underlying human genetic disease. Hum Genomics. 2012;6:27. http://dx.doi.org/10.1186/1479-7364-6-27

22. Dhallan $R$, Guo $X$, Emche $S$, et al. A non-invasive test for prenatal diagnosis based on fetal DNA present in maternal blood: a preliminary study. Lancet. 2007;369:474-81. http://dx.doi.org/10.1016/S0140-6736(07)60115-9

23. Dondorp W, de Wert G, Bombard Y, et al. Non-invasive prenatal testing for aneuploidy and beyond: challenges of responsible innovation in prenatal screening. Eur J Hum Genet. 2015;23:1-13.

24. Hills A, Donaghue C, Waters J, et al. QF-PCR as a stand-alone test for prenatal samples: the first 2 years' experience in the London region. Prenat Diagn. 2010;30:509-17. http://dx.doi.org/10.1002/pd.2503 


\title{
Sadašnjost i budućnost prenatalne dijagnostike u Sloveniji
}

\author{
M. Volk, N. Teran, A. Maver, L. Lovrečić, B. Peterlin
}

Prenatalno genetičko testiranje u nadležnosti je Državne zdravstvene djelatnosti u Sloveniji i uključeno je u kliničku praksu od 1980.-ih godina. Prenatalne usluge tradicionalno obuhvaćaju kariotipiziranje i brz probir na fetalne aneuploidije kako bi se otkrile kromosomne anomalije, dok se za poremećaje jednog gena provodilo ciljano testiranje na mutacije. Razvoj komparativne genomske hibridizacije na mikropostroju i sekvenciranje sljedeće generacije omogućava analizu genoma uz bolju rezoluciju u jednom testu. Dok se tehnološki napredak u medicini nastavlja poboljšavajući tako dijagnostičku točnost i šireći lepezu indikacija, ove inovacije zahtijevaju sve veća ulaganja i sve više opreme te dodatno osposobljeno osoblje koje će raditi s tom opremom, što opterećuje zdravstvene fondove i povećava troškove. To nas potiče da razmotrimo kako uklopiti nove tehnike u postojeću službu kako bismo genetičkeusluge prilagodilipotrebama 21. stoljeća. Ciljnamje razvitinov pristup prenatalnojgenetici kojim ćese postići najučinkovitiji rezultati uz prihvatljive troškove.

Ključne riječi: genetsko testiranje; genomske aberacije; prenatalna dijagnoza 